\title{
THE IMPACT OF HUMAN LAND USE ON THE COMPOSITION AND RICHNESS OF GROUND AND DUNG BEETLE ASSEMBLAGES
}

\author{
PLEXIDA, S.G. ${ }^{1}$ - SFOUGARIS A.I. ${ }^{1}$ - PAPADOPOULOS, N.T. ${ }^{2}$ \\ ${ }^{1}$ Laboratory of Ecosystem and Biodiversity Management, Department of Agriculture, Crop \\ Production and Rural Environment, University of Thessaly \\ Fytokou str., N. Ionia, 38446 Volos, Greece \\ (phonelfax: +30 2421093274; e-mail: splexida@yahoo.gr,asfoug@agr.uth.gr) \\ ${ }^{2}$ Laboratory of Entomology and Agricultural Zoology, Department of Agriculture, Crop \\ Production and Rural Environment, University of Thessaly \\ Fytokou str., N. Ionia, 38446 Volos, Greece \\ (phone/fax: +30 2421093285; e-mail: nikopap@agr.uth.gr) \\ *Corresponding author \\ e-mail:asfoug@agr.uth.gr \\ (Received $3^{\text {rd }}$ Feb 2012; accepted $22^{\text {nd }}$ July 2014)
}

\begin{abstract}
This paper presents the results of a survey on the habitat and seasonal variation in activity density and richness of ground and dung beetle assemblages in a heterogeneous landscape of central Greece. Beetles were collected using 2,646 pitfall traps across an area of 138 ha representative of the Mediterranean mountainous landscape. Sampling was performed in cereal fields, corn fields, fallow land, grassland, Robinia pseudoacacia plantations, oak forest - farmland ecotone and oak forest using pitfall traps. A total of 18,275 individuals belonging to 38 species were collected, whereas only seven species constituted the $82.64 \%$ of the overall captures. Onthophagus ovatus was the most common species in all habitats. Beetle assemblages varied markedly regarding the number of species, while higher densities were reported during June. Significant differences in beetle richness were found considering habitat preferences with the lowest species richness in corn fields. Carabidae assemblages were both most abundant and diverse in plantations, whereas Scarabaeidae assemblages were most abundant and diverse in fallow land. Among estimated diversity indices, Margalef's index generated similar results with the observed diversity, likewise non parametric estimators. Overall, the results obtained in the present study suggest that agricultural areas in mountainous heterogeneous landscape might be the important factor for conserving rich beetle diversity, whereas supplementary biotic factors should be explored.
\end{abstract}

Keywords: Mediterranean ecosystems; Carabidae; Scarabaeidae; habitat heterogeneity;

correspondence analysis

\section{Introduction}

Epigeic invertebrates have been successfully used as biological indicators of ecosystem health and habitat evaluation in a variety of studies (Redolfi et al., 1999; Vanbergen et al., 2005; Liu et al., 2006) focusing either on specific species or families or even on the whole order. A considerable effort has been invested in various aspects of their ecology, especially regarding effects of habitat heterogeneity and habitat loss on their activity density and distribution (Driscoll and Weir, 2005), and effects of the geographical location on their population sustainability (Thomas et al., 2001; Holland et al., 2004).

Among epigeic invertebrates, the most common ones are ground (Carabidae) and dung (Scarabaeidae) beetles. Most commonly ground beetles constitute an important group for comparative ecological studies since they are abundant, their ecology and

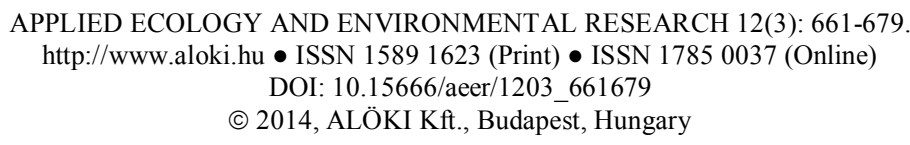


systematics are well known (Lövei and Sunderland, 1996) and are sensitive to habitat changes as well (Niemelä et al., 1993). In addition, they are easily collected, allowing a standardized successful sampling, while some are highly selective and restricted to a particular habitat (Niemelä et al., 1992). Dung beetles though have proved to be key organisms in nutrient poor systems (Piñero and Avila, 2004), aerating and softening the soil (Brusaard, 1987; Herrick and Lal, 1996). However, only recently have they received increasing attention as indicators of changes in land use (Spector, 2006; Barragan et al., 2011) and the health status of pastures (Davis et al., 2004). Nonetheless, they have been scarcely studied in the Mediterranean region, except for some western European regions (France and Iberian Peninsula) and the western Rhodopes Mountains of Greece (Lobo et al., 2007). Wassmer (1995) studied the habitat selection of coprophagous beetles in southwestern Germany resulting in main differences comparing to other investigations from other geographic latitudes reflecting the variability within widely distributed species which are an ultimate reason for their expansion.

Several recent studies are dealing with beetle diversity in mountain landscapes of different geographical areas such as Iberian Peninsula (Lobo and Martin-Piera, 1999; Zamora et al., 2007) and a forested landscape of Mexico (Navarette and Halffter, 2008). It seems that habitat type and structure drive local species richness (Tews et al., 2004), whereas habitat heterogeneity is positively correlated with high diversity levels (Brose, 2003). Moreover, several studies have recorded higher diversity levels in agriculture unit (da Silva, 2008), tallgrass prairies (Larsen et al., 2003), mown meadows and riparian woodlands (Gutiérrez et al., 2004) than in other habitats. Contrasting results could reflect differences in habitat heterogeneity between study areas so there is a need for a closer examination of the effect of habitat heterogeneity on beetle diversity. Furthermore, forest edges with increased beetle species richness substantiate a significant edge effect (Báldi and Kisbenedek, 1994; Magura, 2002).

Despite the fact that Mediterranean area is one of the world's richest regions in terms of animal and plant diversity (Myers et al., 2000; Verdú et al., 2000; Atauri and de Lucio, 2001; Burel et al., 2004; Cuttelod et al., 2008), there is only a handful of studies dealing with beetle distribution in upland landscapes of Greece. For example, Trichas (1997) studied the ecology and biogeography of ground coleoptera in the southern Aegean area, with emphasis on seasonal composition of Carabidae and Tenebrionidae assemblages, Anastasiou and Legakis (2002) studied the distribution of Carabidae in some mountains of Peloponnese, southern Greece, whereas Pitta (2009) studied the communities of soil arthropods in a mosaic of sites in different succesional stages on mountain Parnitha after fire. In northern Greece, Argyropoulou et al. (2005) described and compared the community organization patterns of Coleoptera in various sites of the Dadia forest reserve, regarding different types of vegetation and management practices. Although these studies have led to a better understanding of beetle diversity, even fewer studies have focused on seasonality and assemblage structure of ground and dung beetles (Theile, 1977; Jay-Robert et al., 1997; Errouissi et al., 2004). Finally, there has been no investigation on the relative contribution of cereal cultivation and adjacency with semi-natural habitats in mountainous landscapes on beetle richness. This lack of knowledge could lead to unsustainable land use management, as these insects play a crucial role in many ecosystem functions.

The aim of the current paper was to study the relationship between habitat heterogeneity and beetle richness in an upland Mediterranean landscape where agriculture is dominated by cereals. The specific objectives of the study were to 
investigate: (1) the species diversity of the landscape using beetles as an indicator taxon, (2) the seasonal distribution patterns of ground and dung beetle assemblages throughout their activity season; (3) whether habitat haterogeneity influences beetle species richness across cereal fields and neighbouring semi-natural habitats and (4) whether ground and dung beetle assemblages respond similarly to habitat heterogeneity.

\section{Materials and methods}

\section{Study area}

The study was conducted in a heterogeneous Mediterranean landscape of western Thessaly, in central Greece (Flabouresi, $33 \mathrm{~km}$ NE of Kalabaka town), (39 $50^{\circ} 44^{\prime \prime} \mathrm{N}$ and $\left.21^{\circ} 42^{\prime} 30^{\prime \prime} \mathrm{W}\right)($ Fig. 1A). The study area is part of the Natura 2000 site "Antichasia Meteora Mountains", which is considered as an important area for bird species of european conservation concern (Meliadis and Kassioumis, 2001), the endemic plant species Centaurea kalambakensis (Freyn \& Sint) and Centaurea lactiflora (Halácsy) (Asteraceae) and endangered insects such as Rhysodes sulcatus (Dalman) (Carabidae) (Legakis and Maragou, 2009).

The area of Flabouresi (altitude $\approx 800 \mathrm{~m}$ above sea level) consists of a mosaic of agricultural fields (412 ha) (Fig. 1B) surrounded by forests dominated by Quercus pubescens (Willdenow) (Fagaceae). The topography of the southern slopes is moderate (average slope $<30^{\circ}$ ), whereas all other slopes are relatively low (average slope $<15^{\circ}$ ). The climate is characterized as typical sub-Mediterranean, with warm, dry summers, and mild, wet winters. The average monthly temperature ranges from $15.5^{\circ} \mathrm{C}$ (January) to $26.9{ }^{\circ} \mathrm{C}$ (August), while the annual rainfall averages $\approx 700 \mathrm{~mm}$ (data from Kalabaka Meteorological Station, $27 \mathrm{~km}$ away). The dry period lasts from middle June to middle September.

Livestock (sheep, goats and cattle) grazing, along with agriculture, are the main productive activities of the area. The fieldwork was conducted in a total area of 138 ha:

- 61 ha of dry winter wheat [(Triticum aestivum Linnaeus (Poaceae)]), planted in mid September and harvested in late July;

- 6 ha of dry corn fields [(Zea mays Linnaeus (Poaceae)], planted in late May and harvested in late August;

- 9 ha of fallow land, plowed agricultural land unseeded for two or more growing seasons with short vegetation cover;

- 27 ha grazed grasslands, non fertilised, including mostly Anthemis arvensis, Avena fatua, Convolvulus arvensis, Lolium sp., Poa annua, Poa pratensis; Senecio vulgaris and Vicia cracca;

- 12 ha of managed Robinia pseudoacacia Linnaeus (Fabaceae) plantations, 10year old trees up to 8-10 m high;

- 8 ha oak forest, 15-year old trees up to 15-20 m high dominated by Quercus pubescens, Q. frainetto and Q. ithaburensis var. cerris forming a sparse forest and

- 15 ha oak forest - farmland ecotones adjoining forests with other habitats. 

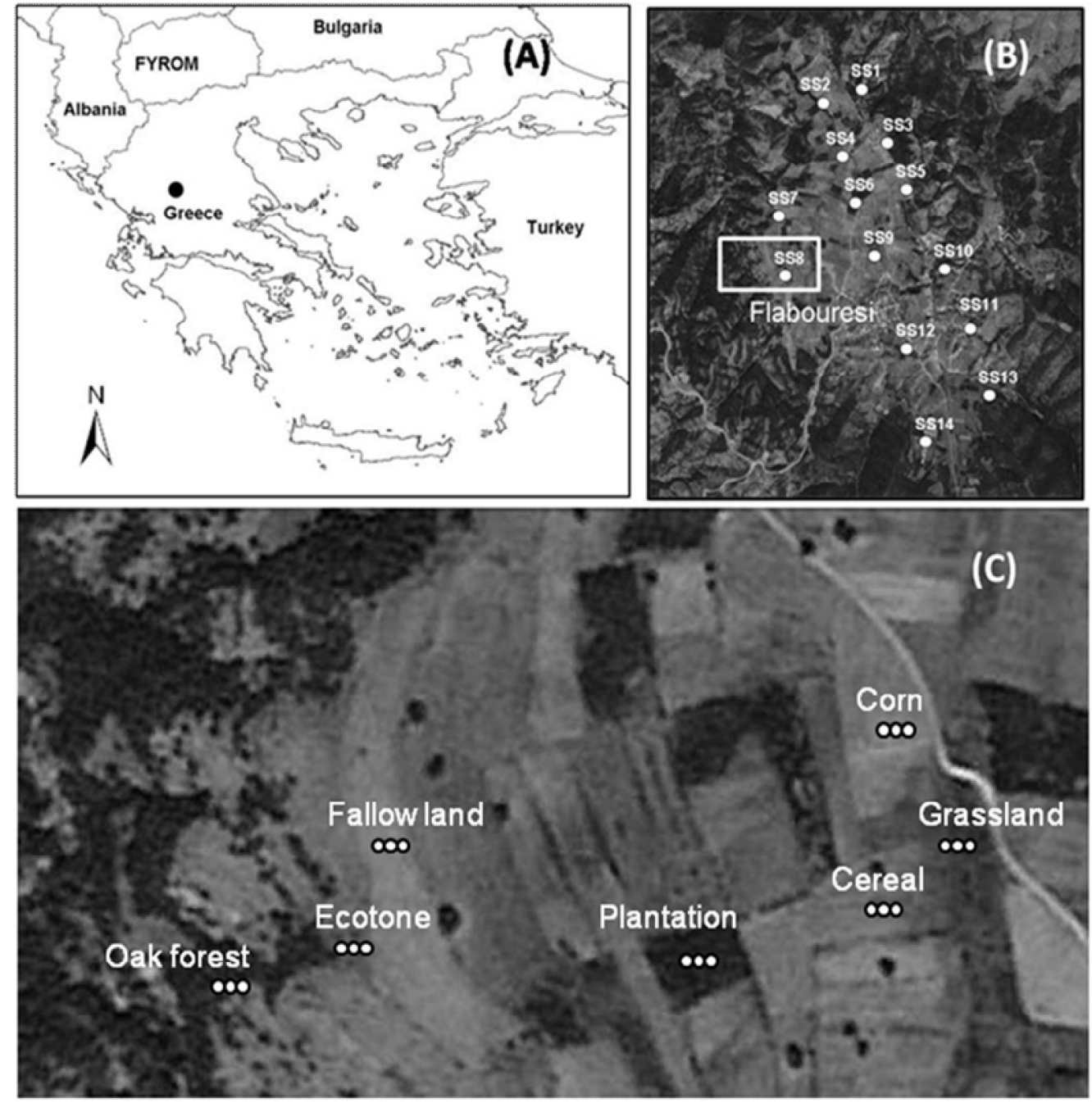

Figure 1. a) The study area, b) the 14 sampling sites (SS) and c) the sampling design of the pitfall traps at one of the 14 sampling sites

\section{Beetle sampling}

Beetles were sampled at 14 sites (Fig. 1B) using plastic pitfall traps (diameter $9 \mathrm{~cm}$, depth $13 \mathrm{~cm}$ ) filled with $250 \mathrm{ml}$ water plus $0.25 \%$ household vinegar (5\% acetic acid) as a preserving solution (Thomas and Marshall, 1999). Each sampling site included all 7 habitats (see above). Pitfall traps were used to sample beetles as a very convenient and easy-to-operate method, yielding highly standardised samples (Southwood and Henderson, 2000). Collected samples ( 3 traps x 7 habitats x 14 sites x 9 months $=$ total 2,646 traps) (Fig. 1C) were analysed in the laboratory. The distance between each trap was $\approx 10 \mathrm{~m}$, for avoiding inter trap effects (Digweed et al., 1995), and within $10 \mathrm{~m}$ of each habitat fragment, so that trap catches represent the assemblage within that habitat. Pitfall traps were placed from 25 May 2006 until 15January 2007 for two consequent days (48 h) per month, to prevent oversampling that might have an excessive impact on the density of beetles and minimize depletion of the insect fauna. All pitfall traps were placed so that the lip of the cup to be slightly below of the ground surface in a fixed position throughout the sampling period. In few cases during the trapping period the 
solution was diluted by rainwater, but none of the traps overflowed. Five traps from the grasslands and 7 from the fallow land were excluded due to the severe damage by grazing animals. The geographical position of each pitfall trap was recorded using a global positioning system (GPS; e-Trex Vista, Garmin Co. Ltd.). Adult specimens were taken to the laboratory and identification to species level was accomplished using dichotomus keys (Chinery, 1993; Gueorguiev and Gueorguiev, 1995; Chinery, 2000) following the nomenclature of Fauna Europaea (Vigna-Talianti, 2007).

\section{Statistical analysis}

The numerical importance of each species in the structure of the whole community was computed by the total number of captured individuals $(\mathrm{N})$, the relative activity density $(\%)$ and the species occurrence $(\% \mathrm{O})$ defined as the pure records of locations where a species occurred (Tsoar et al., 2007). To compare the variation of beetle assemblages among the different habitat types, the total number of activity densities and number of species per three trap complex (within habitat within site) were used. Values of variables were compared by an ANOVA, followed by the Tukey's $b$ test. If assumptions of normality and homogeneity of variances (using Kolmogorov-Smirnov test and $F$ test respectively, Sokal and Rohlf, 1995), were not met, data were transformed according to the method Box-Cox (Draper and Cox, 1969).

Although species richness is generally the most relevant component of the beetle diversity, alpha diversity was also calculated by three indices: i) the Shannon-Weiner index $\left(H^{\prime}\right)$ (Shannon and Weaver, 1949), despite its sensitivity to the presence of rare species: $H^{\prime}=-\Sigma \mathrm{p}_{\mathrm{i}} \ln \mathrm{p}_{\mathrm{i}}$, where $p_{i}$ is the proportion of the $i$ th species among the total collected; ii) the Berger-Parker's index $(B P I)$, which is a measure of the numerical importance of the most abundant species: $B P I=\mathrm{N}_{\max } / \mathrm{N}$ where $\mathrm{N}_{\max }$ is the number of individuals of the most abundant species, and $\mathrm{N}$ is the total number of individuals in the sample; and iii) Margalef's diversity index $\left(D_{M g}\right)$, which balances the richness by the beetle numbers (Magurran, 1988): $D_{M g}=(\mathrm{S}-1) / \ln \mathrm{N}$, where $\mathrm{S}$ is the number of species and $\mathrm{N}$ is the number of individuals.

To estimate species richness instead of the observed number of species (Brose, 2002; Chao, 2005), we tested the following four nonparametric estimators: i) Chao 2, ii) $1^{\text {st }}$ Order Jacknife, iii) $2^{\text {nd }}$ Order Jacknife and iv) Bootstrap. These nonparametric species richness estimators use the sample-based data to estimate the total number of species (Gotelli and Colwell, 2001; Chao and Bunge, 2002). All alpha diversity and nonparametric indices were generated using the software Species Diversity and Richness ver. 4.0 (PISCES Conservation Ltd 2006). The randomization test of Solow (1993) and the t-test were used to assess the significance of differences in diversity and richness along the different habitat types at the significance level 0.05 .

To investigate the seasonal patterns of both beetle families mean values $( \pm \mathrm{SE})$ of activity densities and species richness were calculated and presented graphically per month. To analyse the variation over time in activity densities and species richness of ground and dung assemblages along the various habitat types, repeated measures ANOVA was used followed by the Tukey's $b$ test. The model included "habitat type" being the fixed factor (seven levels: cereal, corn, fallow, grassland, Robinia pseudoacacia plantation, oak forest - farmland ecotone and oak forest), "season" being the repeated factor (seven out of nine sampling periods, since there was no pitfall catches in December and January) and the interaction between the two variables. All 
data analyses were performed using the PASW Statistics 19 (SPSS Inc., Chicago, USA).

To explore the beetle compositional variation and find possible differences among different habitats, Correspondence Analysis (CA) (ter Braak and Smilauer, 2002) and the xlstat v. 2011.3.02 statistical analysis software (http://www.xlstat.com) were used. The multivariate data of species composition of the census points were analyzed by CA, which ordinated individual samples in a way that the differences among them would be maximized. Correspondence analysis was applied to the species $\mathrm{x}$ trap catches in order to reveal the relationships between a species and trap locations.

\section{Results}

\section{Species composition and richness}

A total of 18,275 adult beetles belonging to 38 species and 20 genera were collected throughout the sampling period (Table 1). A percentage of approximately $0.24 \%$ of the whole captured specimens was not identified to species level because they had decayed in the trap. The number of singletons (species with only one individual) was 5 carabids, while the captured doubletons (species with only two individuals) were 2 carabids and 1 scarabid in the total 2,646 traps. The most abundant subfamilies in terms of the number of individuals recorded were: Scarabaeinae $(\mathrm{N}=15,706)$, Harpalinae $(\mathrm{N}=1,958)$ and Carabinae $(\mathrm{N}=559)$. The most numerous in terms of number of species within ground and dung beetle assemblages in comparison to all other genera were the genus Pterostichus and Onthophagus, respectively. Regarding ground beetle assemblages, the most frequently occurring species were: Pterostichus nigrita (Paykull), P. cupreus (Bonelli), Carabus nemoralis (Linnaeus) and Myas chalybaeus (Palliardi), whereas Onthophagus ovatus (Linnaeus), O. coenobita (Herbst) and Gymnopleurus mopsus (Pallas) were the most abundant dung beetles. Zabrus tenebrioides (Goeze), which is the most important pest for cereals of the captured species, was firstly captured in late July in the $R$. pseudoacacia plantations. A total of 67 individuals were captured throughout the entire sampling period. During the same period only 2 to 3 individuals of the species were captured in wheat and corn respectively. Twenty four out of the 38 species were classified as rare species representing less than $0.1 \%$ of all beetles collected (Table 1). Some of the most abundant species were captured in a small proportion of traps. For example, 2,086 individuals of $O$. coenobita were captured in 69 pitfall traps.

\section{Habitat effects}

Significantly different beetle richness was detected among habitats denoting habitat preferences (carabid species richness, $F=7.548, p<0.0001$; scarabid species richness, $F=10.397, p<0.0001$ ), whereas both assemblages exhibited the lowest species richness in corn fields (Table 2). Regarding the ground beetle assemblage, the highest number of species was recorded in grasslands, whereas similar number of dung beetle species was counted in fallow land. Oak forest was completely dominated by three species: $C$. nemoralis (total number of captured individuals $\mathrm{N}=141$ ), O. ovatus $(\mathrm{N}=162)$ and M. chalybaeus $(\mathrm{N}=141)$. O. ovatus was also common in all other habitats, whereas the other two species occurred mostly in the oak forest. Similarly, significantly different beetle activity densities were found among habitats showing their habitat preferences 
(carabid activity density, $F=5.986, p<0.0001$; scarabid activity density, $F=6.543, p<$ $0.0001)$. Most common scarabids were captured within the plantations, whereas dung beetles were dominant in the catches from the fallow land.

Table 1. Overview of individuals trapped in the different habitats in pitfall traps in Flabouresi during $2006(n=294)$. N: Total number of captured individuals; \%: Relative activity density of each species in relation to the total number; $f$ : Number of pitfall traps where the species was trapped, and O: species occurrence (in percentage) in total sampled traps

\begin{tabular}{|c|c|c|c|c|c|c|c|c|c|c|c|c|}
\hline \multirow[t]{2}{*}{ Family } & \multirow[t]{2}{*}{ Species } & \multicolumn{7}{|c|}{ Habitat } & \multirow[t]{2}{*}{ Total } & \multirow[t]{2}{*}{$\%$} & \multirow[t]{2}{*}{ f } & \multirow[t]{2}{*}{$\% \mathbf{O}$} \\
\hline & & $\begin{array}{l}\text { Cereal } \\
\text { fields }\end{array}$ & \begin{tabular}{|l|} 
Corn \\
fields \\
\end{tabular} & \begin{tabular}{|c} 
Fallow \\
land
\end{tabular} & Grassland & Plantations & Ecotone & $\begin{array}{c}\text { Oak } \\
\text { forest }\end{array}$ & & & & \\
\hline \multirow{28}{*}{ Carabidae } & Acinopus sp. L. & - & - & - & - & - & 2 & - & 2 & 0,01 & 2 & 0,68 \\
\hline & Amara similata $\mathrm{G}$. & - & 1 & - & - & 1 & - & - & 2 & 0,01 & 1 & 0,34 \\
\hline & Amara aenea De Geer & - & - & - & - & 1 & - & - & 1 & 0,01 & 8 & 2,72 \\
\hline & Amara sp. B. & - & - & - & 1 & - & - & - & 1 & 0,01 & 2 & 0,68 \\
\hline & Amara aulica $\mathrm{P}$. & 14 & - & 1 & - & - & 6 & 1 & 22 & 0,12 & 1 & 0,34 \\
\hline & Anchomenus dorsalis $\mathrm{L}$. & 1 & 1 & - & 1 & 1 & - & - & 4 & 0,02 & 4 & 1,36 \\
\hline & Brachinus crepitans $\mathrm{L}$. & 3 & - & 1 & 3 & 26 & - & - & 33 & 0,18 & 15 & 5,1 \\
\hline & Carabus coriaceus $\mathrm{L}$. & 25 & 17 & 19 & 27 & 47 & 43 & 7 & 185 & 1,01 & 102 & 34,69 \\
\hline & Carabus violaceus $\mathrm{L}$. & 7 & 5 & 37 & 8 & 22 & 26 & 7 & 112 & 0,61 & 48 & 16,33 \\
\hline & Carabus nemoralis M. & 2 & 3 & 7 & 1 & 39 & 64 & 141 & 257 & 1,41 & 89 & 30,27 \\
\hline & Carabussp. L. & 5 & - & - & - & - & - & - & 5 & 0,03 & 1 & 0,34 \\
\hline & Cicindela campestris $\mathrm{L}$. & - & - & 1 & 9 & - & 1 & - & 11 & 0,06 & 7 & 2,38 \\
\hline & Harpalus zabroides D. & 1 & - & - & - & - & - & - & 1 & 0,01 & 1 & 0,34 \\
\hline & Molops piceus $\mathrm{P}$. & 24 & 7 & 1 & 20 & 16 & 1 & 1 & 70 & 0,38 & 29 & 9,86 \\
\hline & Molops striolatus $\mathrm{F}$. & 7 & 1 & - & 5 & - & - & - & 13 & 0,07 & 3 & 1,02 \\
\hline & Myas chalybaeus $\mathrm{P}$. & 4 & 1 & 2 & 2 & 93 & 44 & 141 & 287 & 1,57 & 74 & 25,17 \\
\hline & Nebria sp. L. & - & - & - & - & 1 & 1 & 1 & 3 & 0,02 & 5 & 1,7 \\
\hline & Poecilus sericeus F. & - & - & 1 & 1 & 6 & 8 & 6 & 22 & 0,12 & 15 & 5,1 \\
\hline & Poecilus cursorius D. & 2 & - & - & 10 & - & - & - & 12 & 0,07 & 7 & 2,38 \\
\hline & Poecilus purpurascens D. & - & - & - & 3 & 1 & - & - & 4 & 0,02 & 2 & 0,68 \\
\hline & Poecilus punctulatus S. & 7 & - & 8 & 1 & 22 & 8 & 12 & 58 & 0,32 & 32 & 10,88 \\
\hline & Poecilussp. B. & - & - & - & - & - & - & 1 & 1 & 0,01 & 7 & 2,38 \\
\hline & Pterostichus cupreus L. & 120 & 46 & 34 & 169 & 107 & 13 & 23 & 512 & 2,8 & 113 & 38,43 \\
\hline & Pterostichus nigrita P. & 155 & 37 & 100 & 168 & 237 & 34 & 14 & 745 & 4,08 & 136 & 46,26 \\
\hline & Rhysodes sulcatus $\mathrm{F}$. & - & - & - & - & - & - & 1 & 1 & 0,01 & 1 & 0,34 \\
\hline & Sphodrus sp. & 1 & 39 & 2 & 2 & 29 & 16 & 32 & 121 & 0,66 & 33 & 11,22 \\
\hline & Zabrus tenebrioides Gze. & 2 & 3 & 6 & 2 & 44 & 9 & 1 & 67 & 0,37 & 7 & 2,38 \\
\hline & Zabrus curtus A.S. & 13 & 1 & 2 & 1 & - & - & - & 17 & 0,09 & & \\
\hline \multirow[t]{10}{*}{ Scarabae idae } & Copris lunaris $\mathrm{L}$. & - & - & 2 & - & - & - & - & 2 & 0,01 & 2 & 0,68 \\
\hline & Copris hispanus $\mathrm{L}$. & - & - & 6 & - & 1 & - & - & 7 & 0,04 & 4 & 1,36 \\
\hline & Gymnopleurus mopsus $\mathrm{P}$. & 231 & - & 350 & 125 & 32 & 72 & 1 & 811 & 4,44 & 62 & 21,08 \\
\hline & Onthophagus ovatus L. & 2230 & 276 & 4451 & 3508 & 664 & 1115 & 162 & 12406 & 67,86 & 171 & 58,16 \\
\hline & Onthophagus coenobita Hbst. & 267 & 3 & 366 & 614 & 50 & 724 & 62 & 2086 & 11,41 & 69 & 23,47 \\
\hline & Onthophagus amyntas $\mathrm{O}$. & 8 & - & - & - & - & - & - & 8 & 0,04 & 2 & 0,68 \\
\hline & Scarabaeus laticollis $\mathrm{L}$. & - & - & 1 & - & - & 1 & 1 & 3 & 0,02 & 3 & 1,02 \\
\hline & Scarabaeus sacer $\mathrm{L}$. & 8 & - & 37 & 8 & 2 & 11 & - & 66 & 0,36 & 28 & 9,52 \\
\hline & Scarabaeus semipunctatus F. & - & - & 4 & 1 & - & - & - & 5 & 0,03 & 4 & 1,36 \\
\hline & Sisyphus scaefferi L. & 33 & - & 69 & 42 & 34 & 84 & 50 & 312 & 1,71 & 19 & 6,46 \\
\hline
\end{tabular}

\section{Beetle diversity}

The relationships between alpha diversity indices and the beetle assemblages among the habitat types varied significantly based on the randomization Solow test (Table 2). According to it, carabids were much more diverse in plantations similar to their activity densities. Low Shannon-Wiener index value was recorded in grasslands although most

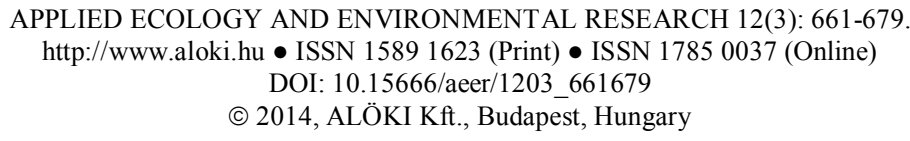


species were caught in this habitat. $B P I$ values were high, meaning dominant species were recorded in this habitat resulting in great sensitivity of $H^{\prime}$ values, which was different from $D_{M g}$ since this is influenced by the rare species of the sample. Scarabids were significantly predominant and rich in fallow land and grasslands. On the contrary, corn fields were significantly poor with a total of only 2 species recorded. However, corn hosted one of the most dominant species (O. ovatus) (Table 1). Furthermore, Margalef's diversity index generated similar results with the observed ones, meaning the lowest value at the corn fields and the highest one at the fallow land.

Table 2. Comparison of activity densities, species richness, values of Shannon-Wiener index $\left(H^{\prime}\right)$, Berger-Parker Index (BPI), Margalef's diversity index (DMg) and estimated non parametric indices of species richness among the different habitats for the total sampling period. Significance of difference in indices values are indicated by the letters " $a$ ", " $b$ ", " $c$ " and " $d$ ". Means followed by the same letter did not differ significantly $(p=0.05)$

\begin{tabular}{|c|c|c|c|c|c|c|c|c|}
\hline Observation & & $\begin{array}{l}\text { Cereal } \\
\text { fields }\end{array}$ & $\begin{array}{l}\text { Com } \\
\text { fields }\end{array}$ & $\begin{array}{c}\text { Fallow } \\
\text { land }\end{array}$ & Grassland & Plantations & Ecotone & Oak forest \\
\hline \multirow[t]{13}{*}{ Carabidae } & Abundance & 380 & 164 & 215 & 426 & 692 & 263 & 383 \\
\hline & Species richness & 19 & 14 & 17 & 21 & 18 & 15 & 15 \\
\hline & $\begin{array}{l}\text { Individuals } \\
(\operatorname{mean} \pm \text { SE })\end{array}$ & $0.97 \pm 0.21 \mathrm{~b}$ & $0.07 \pm 0.15 \mathrm{~b}$ & $0.55 \pm 0.08 \mathrm{~b}$ & $1.09 \pm 0.21 \mathrm{a}$ & $1.76 \pm 0.23 \mathrm{a}$ & $0.67 \pm 0.07 \mathrm{~b}$ & $0.97 \pm 0.17 \mathrm{~b}$ \\
\hline & $\begin{array}{l}\text { Species } \\
(\text { mean } \pm \text { SE })\end{array}$ & $0.16 \pm 0.01 \mathrm{~b}$ & $0.12 \pm 0.02 \mathrm{c}$ & $0.15 \pm 0.02 \mathrm{~b}$ & $0.16 \pm 0.01 \mathrm{~b}$ & $0.26 \pm 0.02 \mathrm{a}$ & $0.22 \pm 0.01 \mathrm{a}$ & $0.18 \pm 0.02 b$ \\
\hline & \multicolumn{8}{|c|}{ Alpha diversity indices } \\
\hline & $\mathbf{H}^{\prime}$ & $1.93 \mathrm{c}$ & $1.87 \mathrm{c}$ & $2.41 \mathrm{a}$ & $1.53 \mathrm{~d}$ & $2.13 \mathrm{~b}$ & $2.18 \mathrm{~b}$ & $1.61 \mathrm{~d}$ \\
\hline & BPI & $0.35 \mathrm{~b}$ & $0.28 b$ & $0.20 \mathrm{~b}$ & $0.45 \mathrm{a}$ & $0.32 b$ & $0.22 \mathrm{c}$ & $0.37 \mathrm{~b}$ \\
\hline & $\mathbf{D}_{\mathbf{M g}}$ & $3.03 \mathrm{c}$ & $2.55 \mathrm{~d}$ & $3.91 \mathrm{a}$ & $3.30 \mathrm{~b}$ & $2.60 \mathrm{c}$ & $2.51 \mathrm{c}$ & $2.35 \mathrm{~d}$ \\
\hline & \multicolumn{8}{|c|}{ Estimated non parametric indices of species richness (mean $\pm S E$ ) } \\
\hline & Chao2 & $13.87 \pm 1.16 \mathrm{a}$ & $12.56 \pm 2.20 \mathrm{a}$ & $27.56 \pm 3.85 b$ & $14.45 \pm 1.34 \mathrm{a}$ & $13.90 \pm 0.86 \mathrm{~b}$ & $13.15 \pm 0.55 b$ & $11.75 \pm 0.76 b$ \\
\hline & $\begin{array}{l}\text { 1st Order } \\
\text { Jadknife }\end{array}$ & $19.51 \pm 1.71 b$ & $15.14 \pm 1.38 \mathrm{c}$ & $16.47 \pm 1.64 a$ & $21.08 \pm 2.15 \mathrm{a}$ & $18.50 \pm 1.17 \mathrm{~b}$ & $15.02 \pm 0.82 \mathrm{c}$ & $14.68 \pm 1.07 \mathrm{c}$ \\
\hline & $\begin{array}{l}\text { 2nd Order } \\
\text { Jacknife }\end{array}$ & $22.46 \pm 2.43 b$ & $15.62 \pm 1.79 \mathrm{c}$ & $19.55 \pm 2.37 \mathrm{a}$ & $25.13 \pm 3.15 b$ & $19.58 \pm 1.95 b$ & $15.16 \pm 1.35 \mathrm{c}$ & $16.48 \pm 1.67 \mathrm{c}$ \\
\hline & Bootstrap & $15.22 \pm 1.63 \mathrm{a}$ & $11.24 \pm 1.34 b$ & $12.76 \pm 1.46 \mathrm{a}$ & $16.16 \pm 1.98 \mathrm{a}$ & $15.55 \pm 1.31 \mathrm{~b}$ & $13.56 \pm 1.14 b$ & $12.55 \pm 1.24 \mathrm{~b}$ \\
\hline \multirow[t]{13}{*}{ Scarabaeidae } & Abundance & 2735 & 273 & 4746 & 4124 & 842 & 1854 & 279 \\
\hline & Species richness & 6 & 2 & 9 & 6 & 6 & 6 & 5 \\
\hline & $\begin{array}{l}\text { Individuals } \\
(\text { mean } \pm \text { SE })\end{array}$ & $19.53 \pm 0.44 a$ & $1.95 \pm 0.84 \mathrm{c}$ & $33.9 \pm 9.29 \mathrm{a}$ & $29.46 \pm 7.07 a b$ & $6.01 \pm 2.53 \mathrm{c}$ & $13.24 \pm 4.44 b c$ & $1.97 \pm 3.33 \mathrm{c}$ \\
\hline & $\begin{array}{l}\text { Species } \\
(\text { mean } \pm \text { SE })\end{array}$ & $0.25 \pm 0.02 \mathrm{a}$ & $0.08 \pm 0.01 \mathrm{~d}$ & $0.36 \pm 0.03 \mathrm{a}$ & $0.33 \pm 0.04 a b$ & $0.20 \pm 0.03 \mathrm{c}$ & $0.22 \pm 0.03 \mathrm{bc}$ & $0.15 \pm 0.03 \mathrm{~cd}$ \\
\hline & \multicolumn{8}{|c|}{ Alpha diversity indices } \\
\hline & $\mathbf{H}^{\prime}$ & $0.65 \mathrm{a}$ & $0.06 \mathrm{c}$ & $0.63 \mathrm{c}$ & $0.59 \mathrm{a}$ & $0.48 \mathrm{c}$ & $0.80 \mathrm{~b}$ & $0.85 b$ \\
\hline & BPI & $0.81 \mathrm{~d}$ & $0.98 \mathrm{a}$ & $0.83 \mathrm{a}$ & $0.81 \mathrm{~d}$ & $0.88 \mathrm{a}$ & $0.58 \mathrm{c}$ & $0.69 \mathrm{c}$ \\
\hline & $\mathbf{D}_{\mathbf{M g}}$ & $0.63 \mathrm{a}$ & $0.17 \mathrm{~b}$ & $0.94 b$ & $0.60 \mathrm{a}$ & $0.74 b$ & $0.66 \mathrm{~b}$ & $0.71 \mathrm{~b}$ \\
\hline & \multicolumn{8}{|c|}{ Estimated non parametric indices of species richness $($ mean $\pm S E)$} \\
\hline & Chao 2 & $4.82 \pm 0.28 \mathrm{c}$ & $1.48 \pm 0.11 d$ & $7.48 \pm 0.39 \mathrm{a}$ & $5.37 \pm 0.28 \mathrm{~b}$ & $4.64 \pm 0.28 \mathrm{c}$ & $4.94 \pm 0.31 \mathrm{c}$ & $3.97 \pm 0.25 \mathrm{~d}$ \\
\hline & $\begin{array}{l}\text { 1st Order } \\
\text { Jacknife }\end{array}$ & $6.51 \pm 0.39 b$ & $2.02 \pm 0.18 \mathrm{~d}$ & $9.06 \pm 0.61 \mathrm{a}$ & $5.93 \pm 0.27 \mathrm{~b}$ & $5.97 \pm 0.42 \mathrm{~b}$ & $6.52+0.34 b$ & $5.02 \pm 0.42 \mathrm{c}$ \\
\hline & $\begin{array}{l}\text { 2nd Order } \\
\text { Jacknife }\end{array}$ & $5.94 \pm 0.64 b$ & $2.37 \pm 0.38 \mathrm{~d}$ & $9.46 \pm 0.84 a$ & $5.66 \pm 0.44 b$ & $5.86 \pm 2.01 \mathrm{~b}$ & $6.37 \pm 0.62 \mathrm{~b}$ & $5.69 \pm 0.68 \mathrm{c}$ \\
\hline & Bootstrap & $4.96 \pm 0.45 b$ & $1.66 \pm 0.18 \mathrm{~d}$ & $7.42 \pm 0.68 \mathrm{a}$ & $5.79 \pm 0.45 \mathrm{a}$ & $5.18 \pm 0.49 \mathrm{~b}$ & $5.11 \pm 0.48 \mathrm{~b}$ & $4.18 \pm 0.42 \mathrm{c}$ \\
\hline
\end{tabular}


Chao 2 and the Bootstrap generated estimates that were not higher than the observed richness, but $1^{\text {st }}$ and $2^{\text {nd }}$ Order Jacknife estimates, much more similar to each other, were much higher than the observed ones, irrelevant to the beetle family (Table 2). Regarding only Scarabaeidae assemblage, all non parametric indices generated the highest species richness at the fallow land and the lowest one at the corn fields. This is in total accordance with $D_{M g}$ index and the observed values. In addition, the nonparametric estimator Chao 2 showed the same performance as the index $D_{M g}$ referring to both Carabidae and Scarabaeidae assemblages.

\section{Seasonal patterns of ground and dung beetle assemblages}

The seasonal pattern of the 38 species and 18,275 individuals trapped through the sampling period is given in Figure 2. Both carabid and scarabid species richness was highest in June and September and lowest in November. Moreover, there was a high seasonal variation as far as scarabids was concerned between May (total number of individuals $\mathrm{N}=270$ ) and June (total number of individuals $\mathrm{N}=11,149$ ). In addition, during the mid July - September period, scarabids decreased and in turn carabids became predominant in the pitfall catches. Seasonal pattern of activity density was similar to that of species richness with its highest value in June and the lowest one in November. No pitfall catch occurred in December and January.
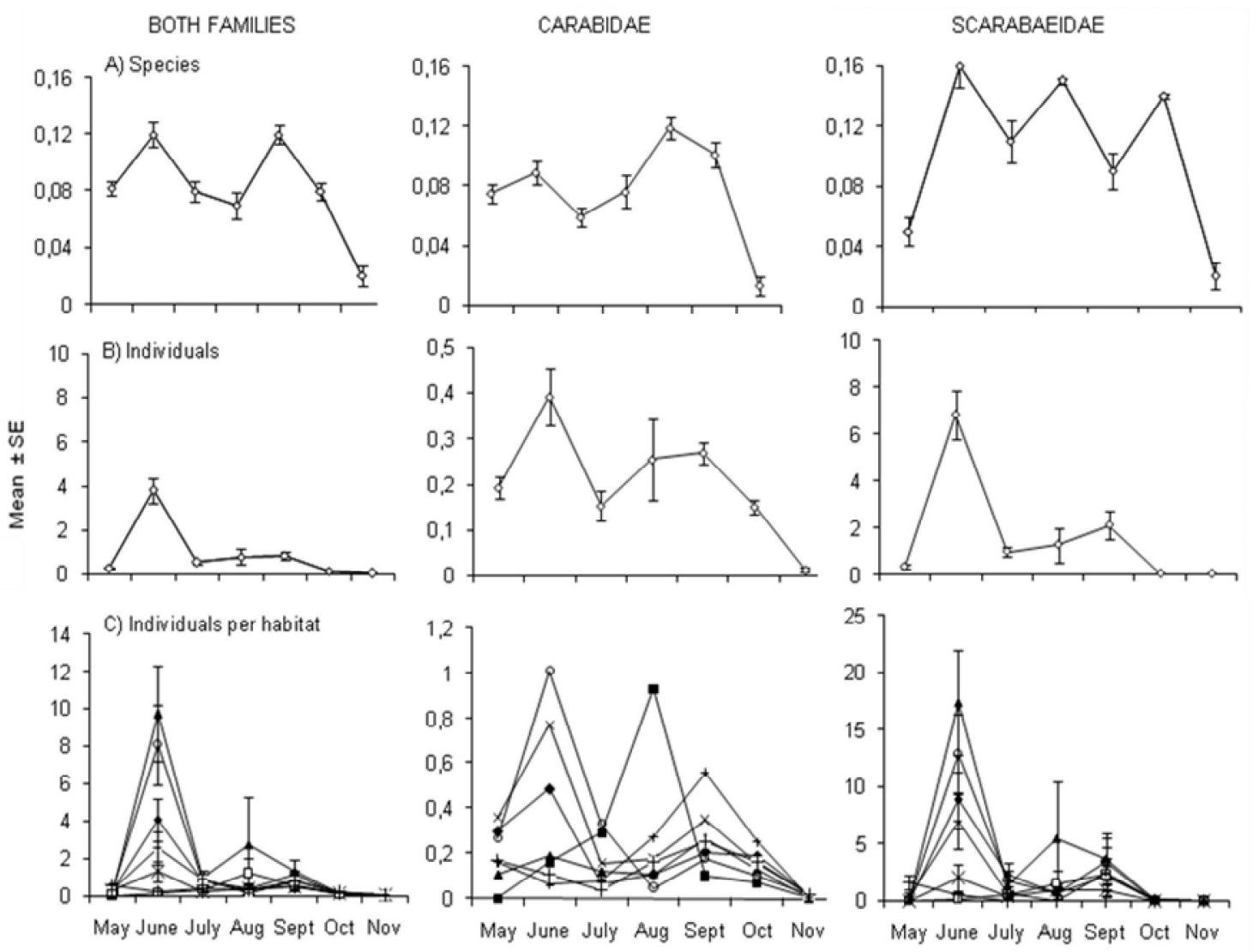

Figure 2. Seasonal patterns of the number of beetles: (A) mean species richness ( $\pm S E),(B)$ mean activity densities $( \pm S E)$, and $(C)$ mean activity densities per habitat type $( \pm S E)(\rightarrow-$, cereal fields; $\square-$, corn fields; $\longleftarrow$, fallow; $\rightarrow$, plantations; $-\bullet$, grassland; -+- , ecotone and $\longrightarrow$ oakforest) 
Based on seasonal activity recorded through the trapping period ground and dung beetles can be classified into two groups (Fig. 3).

Spring breeders appeared early in the season and their activity peaked from May until July. O. coenobita (Fig. 3B), P. cupreus (Fig. 3C) and G. mopsus (Fig. 3F) are characteristic species of that group. The second group, meaning P. nigrita (Fig. 3D) and $S$. scaefferi (Fig. 3E), was active during two periods, early in June and in the middle of September. Cereal fields hosted high beetle catches during the sampling period, while corn fields seemed to be the least preferred habitat (Fig. 2C, Fig. 3).

\section{Habitat and season}

The repeated measures analysis of variance showed that there were significant differences in the activity densities and richness of ground and dung beetles caught in the seven habitats. Habitat type, season and their interaction had a significant effect on the overall number of pitfall catches (Table 3).

A) Onthophagus ovatus

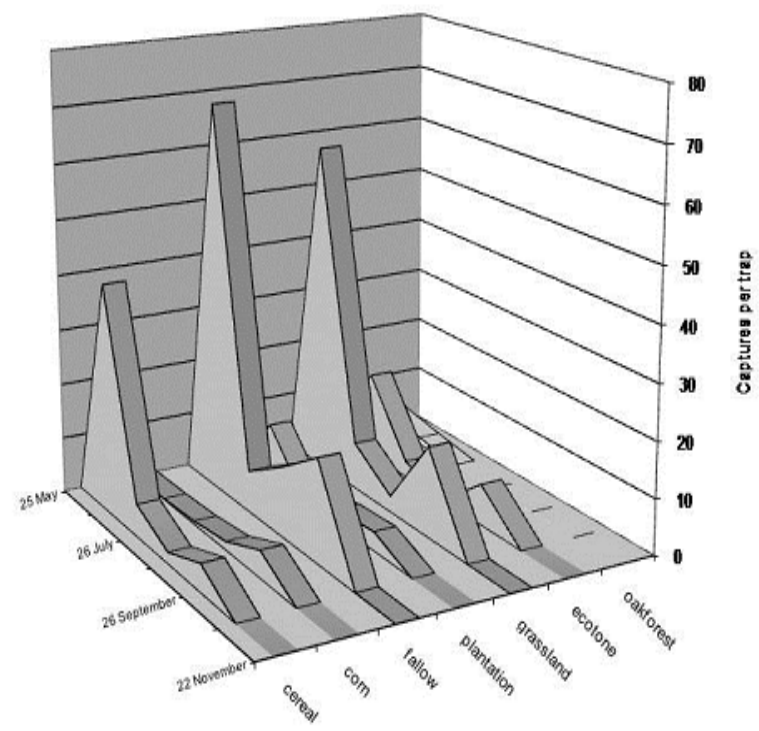

C) Pterostichus cupreus

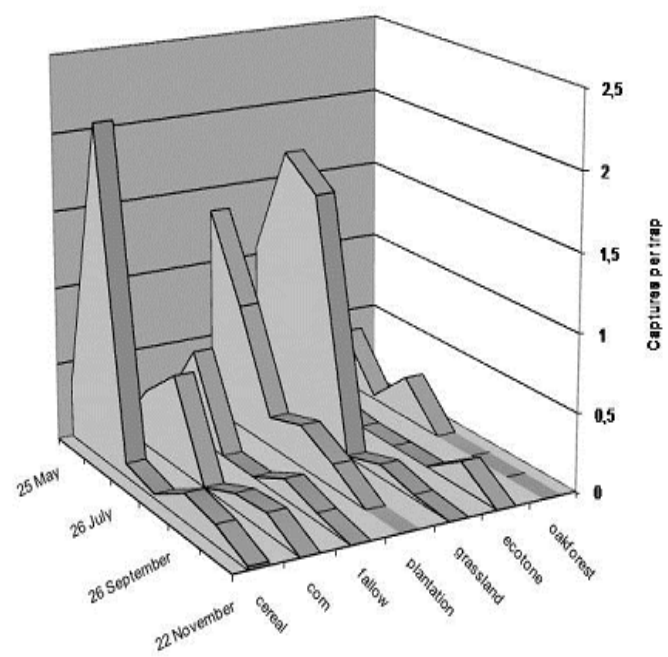

B) Onthophagus coenobita

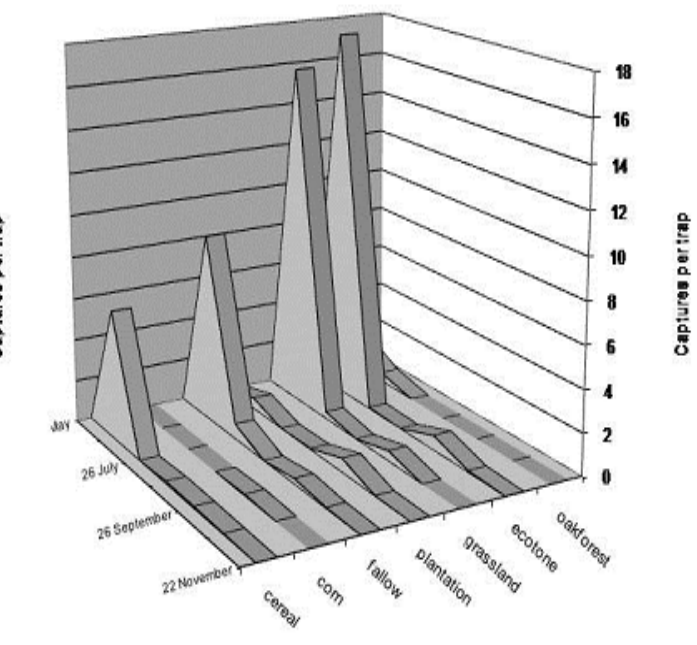

D) Pterostichus nigrita

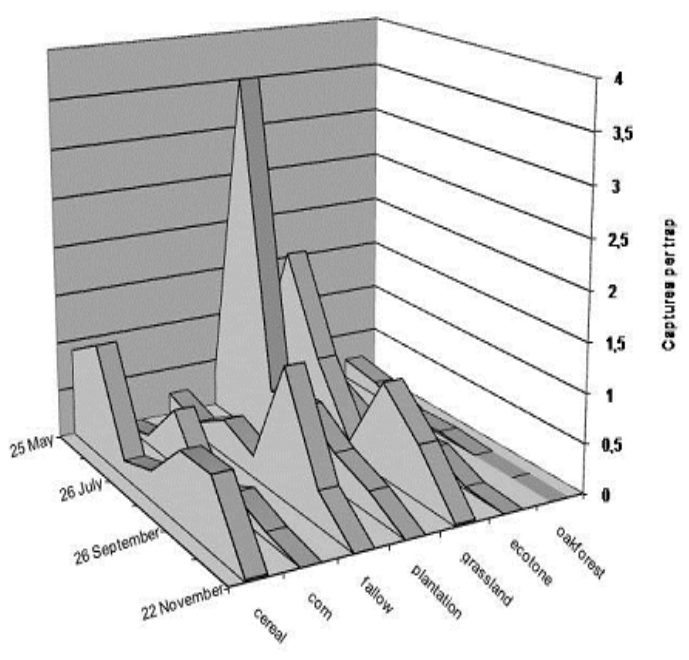




\section{E) Sisyphus scaefferi}

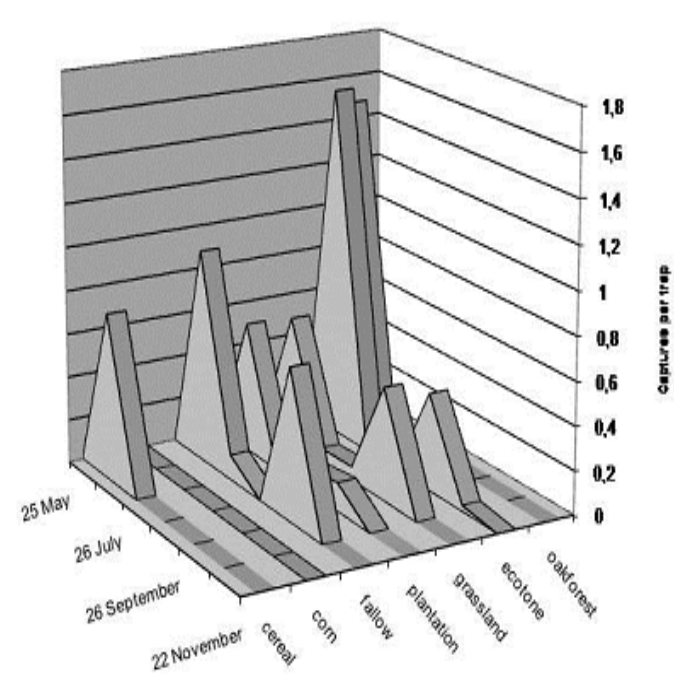

F) Gymnopleurus mopsus

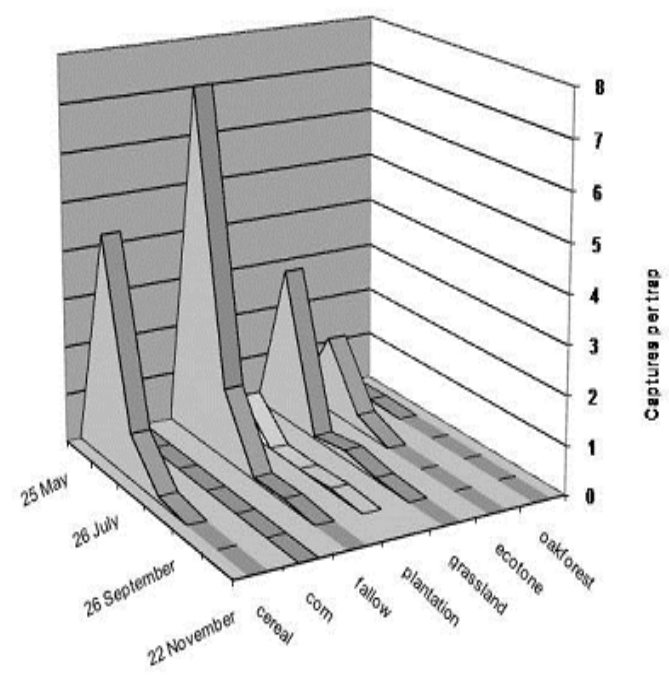

Figure 3. Seasonal patterns of captures of the six most abundant species: A) Onthophagus ovatus B) Onthophagus coenobita C) Pterostichus cupreus D) Pterostichus nigrita E) Sisyphus scaefferi F) Gymnopleurus mopsus

Table 3. Repeated measures analysis of variance (seven monthly counts made from 25 May to 25 November) of beetles in pitfall traps suspended on seven different habitats. Results of the Tukey's $b$ test indicate which habitat type differs significantly $(p<0.05)$ from the others.

\begin{tabular}{|c|c|c|c|c|c|}
\hline $\begin{array}{l}\text { Source of } \\
\text { variation }\end{array}$ & df & MS & $\mathbf{F}$ & $p$ & Tukey's $b$ test \\
\hline \multicolumn{6}{|c|}{ Carabidae species richness } \\
\hline Habitat & 6 & 1.703 & 19.179 & 0.001 & $\begin{array}{r}\text { plantation }>\text { ecotone }=\text { oak } \\
\text { forest }=\text { grassland }=\text { cereal }>\text { fallow }>\text { corn }\end{array}$ \\
\hline Error & 287 & & & & \\
\hline Season & 6 & 33.638 & 73.848 & $<0.001$ & \\
\hline Habitat $x$ & 36 & 1.716 & 3.768 & $<0.001$ & \\
\hline \multicolumn{6}{|l|}{ Season } \\
\hline $\begin{array}{l}\text { Error } \\
\text { (Season) }\end{array}$ & 1722 & 0.456 & & & \\
\hline \multicolumn{6}{|c|}{ Carabidae activity density } \\
\hline Habitat & 6 & 12.558 & 7.405 & $<0.001$ & $\begin{aligned} \text { plantation }>\text { grassland }= & \text { cereal }=\text { ecotone }=\text { oak } \\
\text { forest } & =\text { fallow }>\text { corn }\end{aligned}$ \\
\hline Error & 287 & 1.695 & & & \\
\hline Season & 6 & 204.508 & 22.576 & $<0.001$ & \\
\hline Habitat $x$ & 36 & 38.651 & 4.267 & $<0.001$ & \\
\hline Season & & & & & \\
\hline
\end{tabular}




\begin{tabular}{lccccc}
\hline $\begin{array}{l}\text { Error } \\
\text { (Season) }\end{array}$ & 1.722 & 9.059 & & & \\
$\begin{array}{l}\text { Scarabaeidae species richness } \\
\text { Habitat }\end{array}$ & 6 & 1.169 & 11.579 & $<0.001 \quad$ fallow=grassland=cereal=ecotone $>$ plantation $>$ \\
& & & & & \\
oak forest=corn
\end{tabular}

The inertia percentage of the correspondence analysis for the two main axes generally explained $77.32 \%$ of the species variance. The inertia percentage of the first and the second axis was $60.83 \%$ and $16.49 \%$, respectively. Characteristic species of the cereal fields and grasslands were O. ovatus, P. cupreus and P. nigrita (Fig. 4) showing relative inertia 0.032, 0.035 and 0.045, respectively. G. mopsus, $S$. sacer and $O$. coenobita were proved to be characteristic species for the fallow land. Only $C$. coriaceus (Linnaeus) with relative inertia 0.050 was proven as characteristic species of corn fields, while $P$. sericeus, $C$. nemoralis, $S$. scaefferi and $M$. chalybaeus characterized ecotone and oak forest. B. crepitans was strongly associated with the grassland, while $Z$. tenebrioides was most abundant in the plantations.

\section{Discussion}

\section{Seasonality of beetle assemblages}

Our results indicate that: (a) an upland landscape characterized by habitat heterogeneity shaped mainly by agriculture has rich biodiversity, (b) beetle assemblages show strong seasonality, (c) characteristic species are found depending on habitat type and (d) the intermediate disturbed agricultural land uses have higher species activity densities and richness in comparison to the wooded ones.

In the present study, in an area of 138 ha, 10 dung species were collected, whereas 40 species were sampled in Northern Alps from 250,000 ha (Lumaret and Stiernet, 1989).

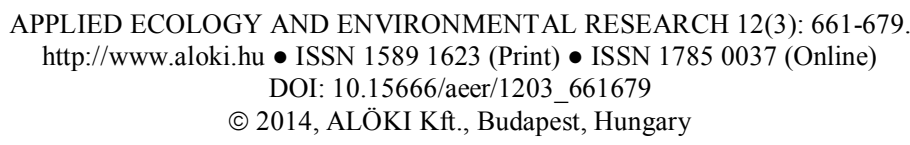


Land uses in our study area and specifically open agricultural areas and grazed grasslands, generate a rather heterogeneous landscape, even at a small scale as multi fragmentation of fields characterizes it. The number of individuals of the Scarabaeidae family (15,706 adult individuals) was high although the number of species was relatively low. Regarding singletons and doubletons, 8 locally rare species were found in our study area, such as the dung beetle Copris lunaris (Linnaeus) and the endangered ground beetle $R$. sulcatus (Legakis and Maragou, 2009). Although recording rare species is crucial as the collective loss of rare taxa could have significant effects on ecosystem functions as well as on the services these systems provide to humans (Lyons et al., 2005), rare insect species have been scarcely studied in Mediterranean mixed forest - agricultural landscapes (Ricarte et al., 2009; Sirami et al., 2010). In our study there were only five individuals of the pest $Z$. tenebrioides collected in crop fields (wheat, 2; corn, 3) probably due to the presence of diverse perennial habitats as Miller and Jones (1997) have reported. This species is a widespread pest in the winter and spring wheat-growing areas of our study area, western and eastern Europe, western Asia, northern Africa and south-central Asia (Bonnemaison, 1980; Burnett, 1984; Borror et al., 1989; Miller, 1991; Remaudière and Remaudière, 1997), causing severe crop losses in wheat monocultures. If it is true that habitat heterogeneity affects negatively its activity densities, then it should be explored from an agronomy point of view.

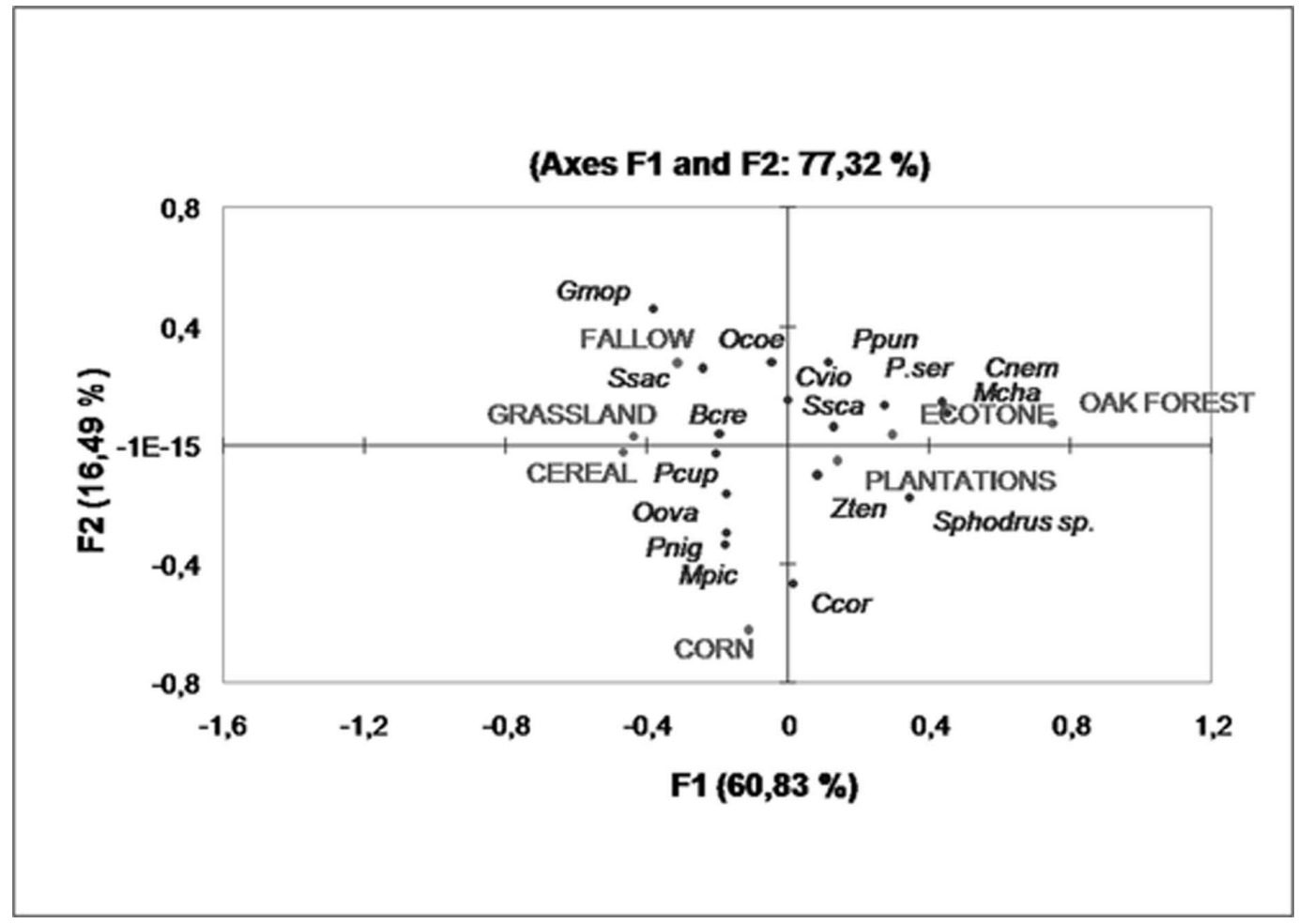

Figure 4. Results of the correspondence analysis: spatial analysis of the species distribution among the habitats. Species names are presented with abbreviations

Our results revealed strong seasonality, with significant differences occurring more within than between the two beetle assemblages. According to other studies, variations in community composition among different seasons are related to changes in 
temperature and humidity that affect activity (Moreno and Halffter, 2001; Romanuk and Kolasa, 2001), seasonal variability in availability of food resources and habitat productivity (Kaspari et al., 2000; Perner et al., 2005), prey availability and vegetation presence (Dennis et al., 1994). In our study, early summer samplings (i.e. June) yielded higher numbers of individuals for both assemblages than those carried out in late summer or winter. Maximum activity density in summer followed by a considerable decrease in late autumn has also been reported by Pinero and Avila (2004) and Sackmann and Flores (2009). Thiele's (1977) classic work suggested that the most frequent carabid captures occur during the season of mating and reproduction. Total activity density of individuals showed fluctuations within the main activity period of beetles (May - July) (Fig. 2). Given that seasonal crops such as wheat are present only for a few months possibly predatory ground beetles may serve as biological agents only during these months. When the cereals are harvested in the middle of July, the adjacent permanent vegetation, e.g. grasslands or fallow land, hosts abundant assemblages (Fig. $3)$. The presence of livestock and dung production across the study area during the summer is of paramount importance for the dung beetles resulting in the enhancement of their population (Romero-Alcaraz and Avila, 2000). In our study area, in late autumn and early winter there are no grazing animals, as the herds are moving to lower elevations, resulting in the significantly dung decrease and probably may affect dung beetle population.

Our results pointed out that habitat heterogeneity had a positive effect on alpha diversity of beetles, with significant variations among seasons. Our results demonstrated that habitat type affected the diversity parameters examined for beetle assemblages, while specific species characterized cereal fields, grasslands, ecotone and oak forest according to the correspondence analysis. Specifically, grasslands and fallow land had higher activity density and species richness of both assemblages in comparison to oak forest. Similarly to our study, Wassmer (1995) showed that population densities of dung beetles were higher in open areas, like pastures, than in the wooded areas, whereas da Silva et al. (2008) reached the same conclusion for ground beetles in Portugal. It has also been suggested that carabids dominate the most exposed habitats like agricultural areas, where they usually find high food availability, caused by the heterogeneity of vegetation (Niemelä, 1997), due to their high mobility and invasive ability (Larsen et al., 2003). The low carabid richness of the forest probably suggests that fewer species are adapted to relatively cool and dark forest habitats (Niemelä, 1993). In our heterogeneous landscape, crops are the most disturbed habitat, due to the complete removal of crop biomass at harvest. Forest is the least affected habitat by the removal of plant biomass in terms of timber; fallow land, plantations and grasslands can be considered intermediate disturbed habitats, falling between crops and forest, as in the latter the vegetation cover is almost permanent, and frequently reduced due to the livestock grazing. The existence of habitat diversity favors the coexistence of species in the area that have different habitat preferences, leading to effective spatial separation of them (Giller and Doube, 1994). On the contrary, some widely distributed species, such as $O$. coenobita, have shown high plasticity in habitat preference across different geographical areas, illustrating possible effects of climatic factors (Lumaret and Kirk, 1987; Wassmer, 1995).

Livestock raising and extensive agriculture should be carried out in such mountainous areas and are strongly recommended in similar landscapes as they have positive effects on the beetle fauna. Similar future studies on the effects of habitat types 
and elements configuration in different spatial and seasonal scales on the beetle fauna, leading to targeted agricultural applications, should be implemented. In addition, biotic factors such as the abundance of predators or prey should be explored to explain habitat heterogeneity - species diversity relationships.

In conclusion, in this upland heterogeneous Mediterranean landscape, significant differences in beetle richness and activity densities were revealed among different seasons and habitats. A striking outcome is that agriculture, which creates habitat heterogeneity in the landscape context, has rather positive effects on beetle diversity. It is also demonstrated that less disturbed habitats, such as the young oak forest in our study area, do not favor diversity. Another apparent outcome is that the estimated non parametric indices performed well comparing to the observed richness, suggesting that they could be used in biodiversity surveys avoiding cost-effective protocols.

Acknowledgments. We are very grateful to Nikolaos Tetagiotis, head of the Kalabaka Forestry Department, for providing us with the management plan and other information concerning Flabouresi forest as well as to the farmers Panagiotis Panagiotou, Konstantinos Panagiotou, Dimitrios Lagopoulos and Christos Lagopoulos for allowing us to conduct the fieldwork (data collection) on their fields. We also thank Dr. C. Nakas (University of Thessaly) for his advice on the statistical analyses.

\section{REFERENCES}

[1] Anastasiou, I., Legakis, A. (2002): Biogeographical analysis of ground beetles (Coleoptera: Carabidae) in the mountainous areas of the Peloponnese. - In: SavopoulouSoultani, M. (Ed.) Proceedings of the 7th European Congress of Entomology. Hellenic Entomological Society, Greece, Thessaloniki, 170 p.

[2] Argyropoulou, M.D., Karris, G., Papatheodorou, E.M., Stamou, G.P. (2005): Epiedaphic Coleoptera in the Dadia forest reserve (Thrace, Greece): the effect of human activities on community organization patterns. - Belg. J. Zool. 135(2): 127-133.

[3] Atauri, J.A., de Lucio, J.V. (2001): The role of landscape structure in species richness distribution of birds, amphibians, reptiles and lepidopterans in Mediterranean landscapes. - Landscape Ecol. 16: 147-159.

[4] Báldi, A., Kisbenedek, T. (1994): Comparative analysis of edge effect on bird and beetle communities. - Acta Zool. Acad. Sci. H. 40: 1-14.

[5] Barragán, F., Moreno, C.E., Escobar, F., Halffter, G., Navarrete, D. (2011): Negative impacts of human land use on dung beetle functional diversity. - PLoSONE 6(3), e17976.doi:10.1371/journal.pone.00179 76

[6] Bonnemaison, L. (1980): Principal animal pests. In E. Hafliger, ed. Wheat, Documenta Ciba-Geigy, Basle, Switzerland, CIBA-GEIGY, pp. 59-68.

[7] Borror, D.J., Triplehorn, C.A., Johnson, N.F. (1989): An introduction to the study of insects, 6th ed. Saunders College Publishing, Philadelphia, PA, USA.

[8] Brose, U. (2002): Estimating species richness of pitfall catches by non-parametric estimators. - Pedobiologia 46: 101-107.

[9] Brose, U. (2003): Bottom-up control of carabid beetle communities in early successional wetlands mediated: by vegetation structure or plant diversity? - Oecologia 135: 407-413.

[10] Brusaard, L. (1987): Kleptocopry of Aphodius coenosus (Coleoptera, Aphodiidae) in nests of Typhaeus typhoeus (Coleoptera, Geotrupidae) and its effect on soil morphology. - Biol. Fert. Soils 3: 117-119.

[11] Burel, F., Butet, A., Delettre, Y.R., Millán de la Penă, N. (2004): Response of selected taxa to landscape context and agricultural intensification. -Landscape Urban Plan 67: 195-204. 
[12] Burnett, P.A. (1984): Cereal crop pests. In: Scott, R.R. (Ed.) New Zealand pest and beneficial insects. Caxton Press, Christchurch, New Zealand, pp. 153-166.

[13] Chao, A., Bunge, J. (2002): Estimating the number of species in a stochastic abundance model. - Biometrics 43: 783-791.

[14] Chao, A. (2005): Species richness estimation, In: Balakrishnan, N., Read C.B., Vidakovic, B. (Ed.), Encyclopedia of Statistical Sciences. Wiley, New York, pp. 79097916.

[15] Chinery, M. (1993): Collins field guide to the insects of Britain and Northern Europe. Harper Collins Publishers, London.

[16] Chinery, M. (2000): Collins guide to the insects of Britain and Western Europe. Harper Collins Publishers, London.

[17] Cuttelod, A., García, N., Abdul Malak, D., Temple, H., Katariya, V. (2008): The Mediterranean: a biodiversity hotspot under threat. In: Vié, J.-C., Hilton-Taylor, C., Stuart, S.N. (Ed.) The 2008 Review of the IUCN Red List of Threatened Species. IUCN Gland, Switzerland.

[18] Da Silva, P.M., Aguiar, C.A.S., Niemelä, J., Sousa, J.P., Serrano, A.R.M. (2008): Diversity patterns of ground-beetles (Coleoptera: Carabidae) along a gradient of land-use disturbance. - Agr. Ecosyst. Environ. 124: 270-274.

[19] Davis, A.L.V., Scholtz, C.H., Dooley, P.W., Bham, N., Kryger, U. (2004): Scarabaeine dung beetles as indicators of biodiversity, habitat transformation and pest control chemicals in agro-ecosystems. - S. Afr. J. Sci. 100: 415-424.

[20] Dennis, P., Thomas, M.B., Sotherton, N.W. (1994): Structural features of field boundaries which influence the overwintering densities of beneficial arthropod predators. - J. Appl Ecol. 31: 361-370.

[21] Digweed, S.C., Currie, C.R., Carcamo, H.A., Spence, J.R. (1995): Digging out the "digging-in effect" of pitfall traps: influences of depletion and disturbance on catches of ground beetles (Coleoptera: Carabidae). - Pedobiologia 39: 561-576.

[22] Draper, N.R., Cox, D.R. (1969): On distributions and their transformations to normality. Journal of the Royal Statistical Society, Series B 31: 472-476.

[23] Driscoll, D.A., Weir, T. (2005): Beetle responses to habitat fragmentation depend on ecological traits, habitat condition, and remnant size. - Conserv. Biol. 19: 182-194.

[24] Errouissi, F., Jay-Robert, P., Lumaret, J-P., Piau, O. (2004): Composition and structure of dung beetle (Coleoptera: Aphodiidae, Geotrupidae, Scarabaeidae) assemblages in mountain grasslands of the southern Alps. - Ann. Entomol. Soc. Am. 97: 701-709.

[25] Gueorguiev, V.B., Gueorguiev, B.V. (1995): Catalogue of the ground-beetles of Bulgaria. - PENSOFT Series Faunistica No 2.

[26] Giller, P.S., Doube, B.M. (1989): Experimental analysis of inter and intraspecific competition in dung beetles. - J. Anim. Ecol. 58: 12942.

[27] Gotelli, N.J., Colwell, R.K. (2001): Quantifying biodiversity: procedures and pitfalls in the measurement and comparison of species richness. - Ecol. Lett. 4: 379-391.

[28] Gutiérrez, D., Menéndez, R., Méndez, M. (2004): Habitat-based conservation priorities for carabid beetles within the Picos de Europa National Park, northern Spain. - Biol. Conserv. 115: 379-393.

[29] Herrick, J.E., Lal, R. (1996): Dung decomposition and pedoturbation in a seasonally tropical pasture. - Biol. Fert. Soils 23: 177-181.

[30] Holland, J.M., Begbie, M., Birkett, T., Southway, S., Thomas, S.R., Alexander, C.J., Thomas, C.F.G. (2004): The spatial dynamics and movement of Pterostichus melanarius and P. madidus (Carabidae) between and within arable fields in the UK. - International Journal of Ecology and Environmental Sciences 30: 35-50.

[31] Jay-Robert, P., Lobo, J.M., Lumaret, J-P. (1997) Altitudinal turnover and species richness variation in European montane dung beetle assemblages. - Arctic Alpine Res 29(2): 196205. 
[32] Kaspari, M., Alonso, L., O'Donnel, S. (2000): Three energy variables predict ant abundance at a geographical scale. Proceedings of the Royal Society B: Biol. Sci. 267: 485-489.

[33] Larsen, K., Work, T., Purrington, F. (2003) Habitat use patterns by ground beetles (Coleoptera: Carabidae) of northeastern Iowa. Pedobiologia 47: 288-299.

[34] Legakis, A., Maragou, P. (2009): The Red Data Book of the Threatened Animals of the Greece. Hellenic Zoological Society. Athens.

[35] Liu, Y., Yu, Z., Gu, W., Axmacher, J.C. (2006): Diversity of carabids (Coleoptera, Carabidae) in the desalinized agricultural landscape of Quzhou country, China. - Agr. Ecosyst. Environ. 113: 45-50.

[36] Lobo, J.M., Martin-Piera, F. (1999): Between-group differences in the Iberian dungbeetle species-area relationship (Coleoptera: Scarabaeidae). - Acta Oecol. 20(6): 587-597.

[37] Lobo, J.M., Chehlarov, E., Guéorguiev, B. (2007): Variation in dung beetle (Coleoptera: Scarabaeoidea) assemblages with altitude in the Bulgarian Rhodopes Mountains: A comparison. - Eur. J. Entomol. 104: 489-495.

[38] Lövei, G., Sunderland, K.D. (1996): Ecology and behaviour of ground beetles (Coleoptera: Carabidae). - Annu. Rev. Entomol. 41: 231-256.

[39] Lumaret, J.-P., Stiernet, N. (1989): Inventaire et distribution des Coléoptè res Scarabéides coprophages dans le massif de la Vanoise. Travaux Scientipques du Parc National de la Vanoise XVII, 193-228.

[40] Lyons, K.G., Brigham, C.A., Traut, B.H., Schwartz, M.W. (2005): Rare species and ecosystem functioning. - Conserv. Biol. 19: 1019-1024.

[41] Magura, T., Tóthmérész, B., Bordán, Z.S. (2002): Carabids in an oak-hornbeam forest: testing the edge effect hypothesis. Acta Biol. Debrecina 24: 55-72.

[42] Magurran, A.E. (1988): Ecological Diversity and its Measurement. Princeton University Press, Princeton, U.S.A.

[43] Meliadis, I., Kassioumis, K. (2001): The combined use of remote sensing and GIS for the study of a Special Protected Area in Greece, In: University of Alicante (Ed.), Proceedings of the 3rd International Conference Ecosystems and Sustainable Development. Alicante, Spain, pp. 409-417.

[44] Miller, R.H. (1991): Insect pests of wheat and barley in West Asia and North Africa. Technical Manual 9 (rev. 2). Aleppo, Syria, ICARDA. 136 p.

[45] Miller, R.H., Jones, M.J. (1997): Fluctuation in a population of ground pearls, Porphyrophora tritici (Bodenheimer) (Homoptera: Margarodidae), in barley in northern Syria. - Rachis 16: 84-85.

[46] Moreno, C.E., Halffter, G. (2001): Spatial and temporal analysis of $\alpha, \beta$ and $\gamma$ diversities of bats in fragmented landscape. - Biodivers. Conserv. 10: 367-382.

[47] Myers, N., Mittermeier, R.A., Mittermeier, C.G., da Fonseca, G.A.B., Kent, J. (2000): Biodiversity hotspots for conservation priorities. - Nature 403: 853-858.

[48] Navarrete, D., Halffter, G. (2008): Dung beetle (Coleoptera: Scarabaeidae: Scarabaeinae) diversity in continuous forest, forest fragments and cattle pastures in a landscape of Chiapas, Mexico: the effects of anthropogenic changes. - Biodivers. Conserv. 17(12): 2869-2898, doi: 10.1007/s10531-008-9402-8.

[49] Niemelä, J., Spence, J.R., Spence, D.H. (1992): Habitat associations and seasonal activity of ground beetles (Coleoptera, Carabidae) in Central Alberta. - Can. Entomol. 124: 521540 .

[50] Niemelä, J., Langor, D., Spence, J.R. (1993): Effects of clear-cut harvesting on boreal ground-beetle assemblages (Coleoptera: Carabidae) in western Canada. - Conserv. Biol. 7: $551-561$.

[51] Niemelä, J. (1997); Invertebrates and boreal forest management. Conserv. Biol. 11: 601610.

[52] Perner, J., Wytrykush, C., Kahmen, A., Buchmann, N., Egerer, I., Creutzburg, S., Odat, N., Audorff, V., Weisser, W. (2005): Effects of plant diversity, plant productivity and 
habitat parameters on arthropod abundance in montane European grasslands. - Ecography 28: 429-442.

[53] Pielou, E.C. (1975): Ecological Diversity. Wiley, New York.

[54] Pinero, F.S., Avila, J.M., 2004. Dung-insect community composition in arid zones of south-eastern Spain. J. Arid Environ. 56, 303-327.

[55] Pitta, E. (2009): Fauna study of epigeic arthropods in different habitat types of mountain Parnitha. Thesis, Department of Biology, University of Patras. doi: http://nemertes.lis.upatras.gr/dspace/handle/12345 6789/1666.

[56] Redolfi, I., Tinaut, A., Pascual, F., Campos, M. (1999): Qualitative aspects of myrmecocenosis (Hym., Formicidae) in olive orchards with different agricultural management in Spain. - J. Appl. Entomol. 123: 621-627.

[57] Remaudière, G., Remaudière, M. (1997): Catalogue des Aphididae du monde. INRA, Paris.

[58] Ricarte, A., Jover, T., Macros-García, M.A., Micó, E., Brustel, H. (2009): Saproxylic beetles (Coleoptera) and hoverflies (Diptera: Syrphidae) from a Mediterranean forest: Towards a better understanding of their biology for species conservation. - J. Nat. Hist. 43 (9): 583-607.

[59] Romanuk, T.N., Kolasa, J. (2001): Simplifying the complexity of temporal diversity dynamics: a differentiation approach. - Ecoscience 8: 259-263.

[60] Romero-Alcaraz, E., Avila, J.M. (2000): Effect of elevation and type of habitat on the abundance and diversity of Scarabaeoid dung beetle (Scarabaeoidea) assemblages in a mediterranean area from southern Iberian peninsula. - Zool. Stud. 39 (4): 351-359.

[61] Sackmann, P., Flores, G.E. (2009): Temporal and spatial patterns of tenebrionid beetle diversity in NW Patagonia, Argentina. - J. Arid Environ. 73: 1095-1102.

[62] Shannon, C.E., Weaver, W. (1949): The mathematical theory of communication. 650 University of Illinois Press, Chicago.

[63] Sirami, C., Nespoulousa, A., Cheyland, J.P., Martya, P., Hvenegaarda, G.T., Geniezh, P., Schatza, B., Martinal, J.L. (2010): Long-term anthropogenic and ecological dynamics of a Mediterranean landscape: Impacts on multiple taxa. Landscape Urban Plan. 96: 214-223.

[64] Sokal, R.R., Rolph, F.J. (1995): Biometry: the principles and practice of statistics in biological research. 3rd ed. W.H. Freeman, New York.

[65] Solow, A.R. (1993): A simple test for change in community structure. - J. Anim. Ecol. 62(1): 191-193.

[66] Southwood, T.R.E., Henderson, P.A. (2000): Ecological methods. 3rd edition. Blackwell Science, Oxford.

[67] Spector, S. (2006): Scarabaeinae dung beetles (Coleoptera: Scarabaeidae: Scarabaeinae): an invertebrate focal taxon for biodiversity research and conservation. - Coleopts. Bull. 60: 71-83.

[68] SPSS for Windows, Rel. 19.0.1 (2008): Chicago: SPSS Inc.

[69] ter Braak, C.J.F., Smilauer, P. (2002): CANOCO Reference Manual and Canoco Draw for Windows User's Guide: Software for Canonical Community Ordination (version 4.5). Microcomputer Power, Ithaca, N.Y, USA.

[70] Tews, J., Brose, U., Grimm, V., Tielbörger, K., Wichmann, M.C., Schwager, M., Jeltsch, F. (2004): Animal species diversity driven by habitat heterogeneity/diversity: the importance of keystone structures. - J. Biogeogr. 31: 79-92.

[71] Thiele, H.U. (1977): Carabid beetles in their environments: A study on habitat selection by adaptations in physiology and behaviour. Springer-Verlag, Berlin and New York.

[72] Thomas, C.F.G., Marshall, E.J.P. (1999): Arthropod abundance and diversity in differently vegetated margins of arable fields. - Agric. Ecosyst. Environ. 72: 131-144.

[73] Thomas, C.F.G., Parkinson, L., Griffiths, G.J.K., Fernández- García, A. (2001): Aggregation and temporal stability of carabid beetle distributions in field and hedgerow habitats. - J. Appl. Ecol. 38: 100-116. 
[74] Trichas, A.E. (1997): Ecology and biogeography of the ground coleoptera in the south Aegean area, with emphasis on composition, seasonal and biotopic Carabidae and Tenebrionidae. Thesis, Department of Biology, University of Crete. doi: http:/elocus.lib.uoc.gr/dlib/a/b/e/ metadata-dlib-1997DIS0025.tkl.

[75] Tsoar, A., Allouche, O., Steinitz, O., Rotem, D., Kadmon, R. (2007): A comparative evaluation of presence-only methods for modeling species distribution. - Divers. Distrib. 13(9): 397-405.

[76] Vanbergen, A.J., Woodcock, B.A., Watt, A.D., Niemelä, J. (2005): Effect of land-use heterogeneity on carabid communities at the landscape scale. - Ecography 28: 3-16.

[77] Verdú, J.R., Crespo, M.B., Galante, E. (2000): Conservation strategy of a nature reserve in Mediterranean ecosystems: the effects of protection from grazing on biodiversity. Biodivers. Conserv. 9: 1707-1721.

[78] Vigna Taglianti, A. (2007): Fauna Europea: Carabidae. In Fauna Europea: Coleoptera 2. Fauna Europaea version 1.1. Edited by P. Audisio. Available from http://www.faunaeur.org.

[79] Wassmer, T. (1995): Selection of the spatial habitat of Coprophagous beetles in the Kaiserstuhl area near Freiburg (SW-Germany). - Acta Oecol. 16(4): 461-478.

[80] Zamora, J., Verdú, J.R., Galante, E. (2007): Species richness in Mediterranean agroecosystems: Spatial and temporal analysis for biodiversity conservation. - Biol. Conserv. 134: $113-121$.

\section{ADDITIONAL WEB RESOURCES}

http://purl.oclc.org/estimates/

www.iucn.org/redlist/

http://www.xlstat.com 